\title{
Networking for conservation: social capital and perceptions of organizational success among land trust boards
}

\author{
Tatyana B. Ruseva ${ }^{1}$, James R. Farmer ${ }^{2}$ and Charles Chancellor ${ }^{3}$
}

\begin{abstract}
As an important component in collaborative natural resource management and nonprofit governance, social capital is expected to be related to variations in the performance of land trusts. Land trusts are charitable organizations that work to conserve private land locally, regionally, or nationally. The purpose of this paper is to identify the level of structural and cognitive social capital among local land trusts, and how these two types of social capital relate to the perceived success of land trusts. The analysis integrates data for land trusts operating in the U.S. south-central Appalachian region, which includes western North Carolina, southwest Virginia, and east Tennessee. We use factor analysis to elicit different dimensions of cognitive social capital, including cooperation among board members, shared values, common norms, and communication effectiveness. Measures of structural social capital include the size and diversity of organizational networks of both land trusts and their board members. Finally, a hierarchical linear regression model is employed to estimate how cognitive and structural social capital measures, along with other organizational and individual-level attributes, relate to perceptions of land trust success, defined here as achievement of the land trusts' mission, conservation, and financial goals. Results show that the diversity of organizational partnerships, cooperation, and shared values among land trust board members are associated with higher levels of perceived success. Organizational capacity, land trust accreditation, volunteerism, and financial support are also important factors influencing perceptions of success among local, nonprofit land trusts.
\end{abstract}

Key Words: land conservation; land trusts; networks; organizational success; social capital

\section{INTRODUCTION}

Nonprofit land trusts are important participants in conserving ecologically rich and socially valuable private lands. By the evolving and increasingly complex nature of community-based land conservation, land trusts bridge sectors and facilitate interactions among private landowners, state and federal agencies, local government, funding organizations, and community groups. To the degree that collective action among these actors is often required to conserve private lands and provide environmental goods and services, such as recreational space, species and habitat conservation, the performance of land trusts can be judged by their ability to facilitate collective action. Social capital in the form of norms and social networks is critical for successful collective action, particularly in the natural resource management arena (Ostrom 1990, 2005). Research shows that trust and shared understandings, common rules, and group connectedness are associated with effective and sustainable resource management (Ostrom 1990, Pretty and Ward 2001, Dietz et al. 2003, Cox et al. 2010, Bodin and Prell 2011).

This study examines the contributions of social capital to successful private land protection by nonprofit land trusts in the U.S. south-central Appalachian region. In 2010, local and state land trusts in the United States held 3.57 million ha of private land protected by conservation easements, but the distribution of these lands was uneven across regions (LTA 2011, Yonavjak and Gartner 2011). Variations in the performance of land trusts reflect differences in the percentage of private land in a state, landowner conservation attitudes, state and federal policy incentives, as well as land trusts' organizational resources and capacity, e.g., financial, human, and social capital (Farmer et al. 2011, Yonavjak and Gartner 2011, Rissman and Sayre 2012, Brenner et al. 2013, Stroman and Kreuter 2014, Sorice et al. 2014). One explanation for differences in the performance of land trusts relates to variations in the level of social capital, an important component in nonprofit governance and collaborative natural resource management (Brown 2007, Jaskyte 2012).

Among land conservancies, and particularly those in rural southcentral Appalachia, social capital is expected to be critical to successful private land protection. Social capital represents the cognitive and structural dimensions of the relationships among people and organizations (Knight et al. 2010). We assess four factors of cognitive social capital (cooperation, shared values, common norms, and communication effectiveness) among land trust board members, as well as structural social capital (size and diversity of organizational networks) for both land trusts and their board members. Although the organizational performance of land trusts reflects the contributions of multiple stakeholders, the board of directors represents the leadership core responsible for the strategic and fiduciary governance of the organization. Board members' human and social capital may, therefore, shape the successful functioning of the organization. To date, few studies have empirically examined the relationship between social capital and land protection, both being integral to the sustainability of social-ecological systems. We maintain that private land conservation rests on individual and organizational level relationships and shared values, which in turn promote successful collective action. We use data from 14 local nonprofit land trusts and their board members to answer the following questions: (1) What is the level of structural and cognitive social capital among land trusts in south-central Appalachia?; (2) How do structural and cognitive social capital relate to the perceived success of land trusts, given a set of organizational and board member specific characteristics?

SOCIAL CAPITAL AND PRIVATE LAND PROTECTION

Social connections and shared norms shape resource exchanges, facilitate the distribution of knowledge and experiences, and influence social and environmental outcomes. This is particularly 
relevant in the private land protection arena, where self-organized community land trusts work with landowners, government, businesses, and other stakeholders to provide a range of environmental public goods and services. In the U.S., voluntary land conservation dates back to the 1880 s, however, land trust growth became dramatic in the 1980s, with changes in the federal tax structure, decline in government land acquisition programs, increased rate of development, and the adoption of the Unified Conservation Easement Act (Gustanski and Squires 2000, King and Fairfax 2006, Brenner et al. 2013).

Land trusts are nonprofit organizations that "actively work to conserve land by undertaking or assisting in land or conservation easement acquisition, or by stewardship of such land or easements" (LTA 2011:4). Conservation easements - a primary tool for private land conservation - are legally binding deed restrictions, e.g., limited or no development, limited land use, or specific management practices, based upon agreement between a property owner and a nonprofit or public conservation organization (Gustanski and Squires 2000, Farmer et al. 2011). Conservation easement preparation often involves different groups and individuals who provide funding, land appraisal, or legal assistance.

This diverse set of participants interact on a spectrum of collaborative initiatives (watershed management, conservation easements), across different sectors (public, private, nonprofit), government levels (federal, state, and local), and social units (organizational or interpersonal interactions) when it comes to the protection of private lands (Imperial 2005, Ansell and Gash 2008). These multifunctional cross-level relationships capture the hierarchical nature of social capital (Grootaert and van Bastelaer 2002; Fig. 1). For local land trusts, social capital exists largely at the community or microlevel, defined by organizational and personal networks, norms, values, trust, and cooperation. These tangible (structural) and less tangible (cognitive) forms of social capital, along with the human capital of board members, provide land trusts with valuable resources.

Fig. 1. Dimensions of social capital by level and type. Quadrants A, B, and C represent the dimensions of social capital operationalized in this study (adapted from Grootaert and van Bastelaer 2002)

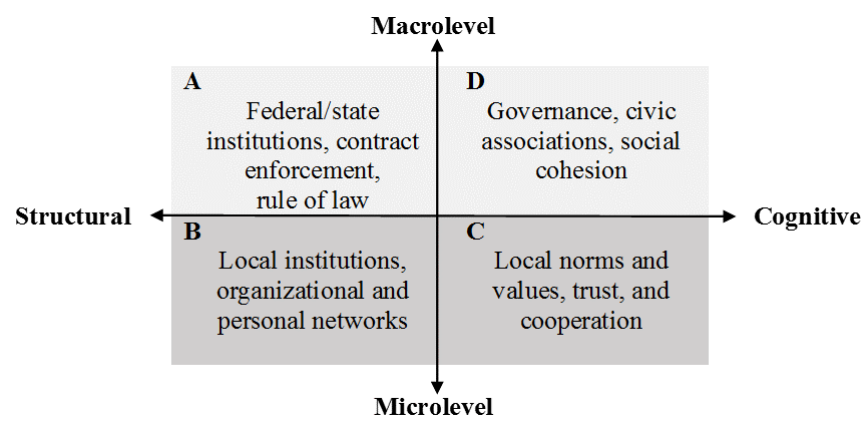

Land trusts rely on the contributions and perspectives of landowners, staff, volunteers, and board members. Although each of these stakeholders contributes to the proper functioning of the organization, the board of directors and executive director represent the organization's leadership core and play a central role in its strategic and fiduciary governance (Jaskyte 2012). Specifically, the board is responsible for upholding the mission, financial, and other values of the land trust, and its decisions and actions ultimately influence the performance of the organization (Bradshaw et al. 1996, Brown 2007, Lichtsteiner and Lutz 2012). In this study, we focus on the competencies land trust board members bring to their organization, such as human and social capital, collectively known as board capital (Hillman and Dalziel 2003, Brown 2007, Vidovich and Currie 2012).

Four components of social capital are important in the natural resource management literature: (1) trust; (2) reciprocity and exchange relationships; (3) common rules and norms; and (4) network or group connectedness (Pretty 2003, Knight et al. 2010). The first three represent the cognitive dimensions of social capital, while network relationships capture the structural dimension (Paletto et al. 2012). In addition to, but separate from these two dimensions, studies have shown the importance of connections within, between, and beyond communities, known as bonding, bridging, and linking social capital (Woolcock 2001, Pretty and Smith 2004).

Bonding social capital reflects relationships between people with similar objectives and outlooks (Pretty and Smith 2004, Berardo 2014, Harrison et al. 2016). The fact that individuals sit on the board of the same land trust could be interpreted as the presence of a common outlook or as a potential opportunity to foster relationships of trust, cooperation, and effective communication (Coleman 1988, Burt 2000, Fischer et al. 2014). Still, comembership should not be taken as a sufficient predictor of the presence or level of bonding social capital (Borgatti and Foster 2003). We, thus, operationalize bonding social capital among board members of a land trust as the cognitive dimension of these relationships (Fig. 1, quadrant C), using a set of questionnaire items to determine the degree to which trust and cooperation, reciprocity, common norms and values are shared among board members.

Bridging social capital represents network connections between land trusts and other entities with different views, such as tourism groups, real estate or business associations (Fig. 1, quadrant B). Bridging capital is positively related to the ability to access resources, engage in collaborative management, facilitate cooperation, and achieve conservation goals (Schneider et al. 2003, Pahl-Wostl et al. 2007, Mandarano 2009, Fisher et al. 2014). The functional diversity of organizational networks at the individual and organizational level is used here as a measure of both bridging and linking social capital. In particular, linking social capital describes land trusts' relationships with groups beyond the local community and with institutions of power, such as state and federal land management agencies; it captures the vertical dimension of social capital (Fig. 1, quadrant A). In short, social capital within, between, and beyond groups, improves access to resources that may otherwise be difficult to obtain, and enhances the likelihood of collective action and the success of land trusts (Borgatti et al. 1998, Burt 2000, Lin 2001, Borgatti and Foster 2003).

In this study cognitive (bonding) social capital is reflected in the level of interpersonal interactions among land trust board members. Structural (bridging and linking) social capital is found in the organizational partnerships and affiliations of both the 
Fig. 2. Study area showing south-central Appalachian region, study counties, and locations of participating land trusts, by central office and total acreage under conservation easement. Some land trusts maintain a central office in a county outside the study area, but operate in counties that are part of south-central Appalachia (VA $=$ Virginia, $\mathrm{TN}=$ Tennessee, $\mathrm{NC}=$ North Carolina, $\mathrm{SC}=$ South Carolina) .

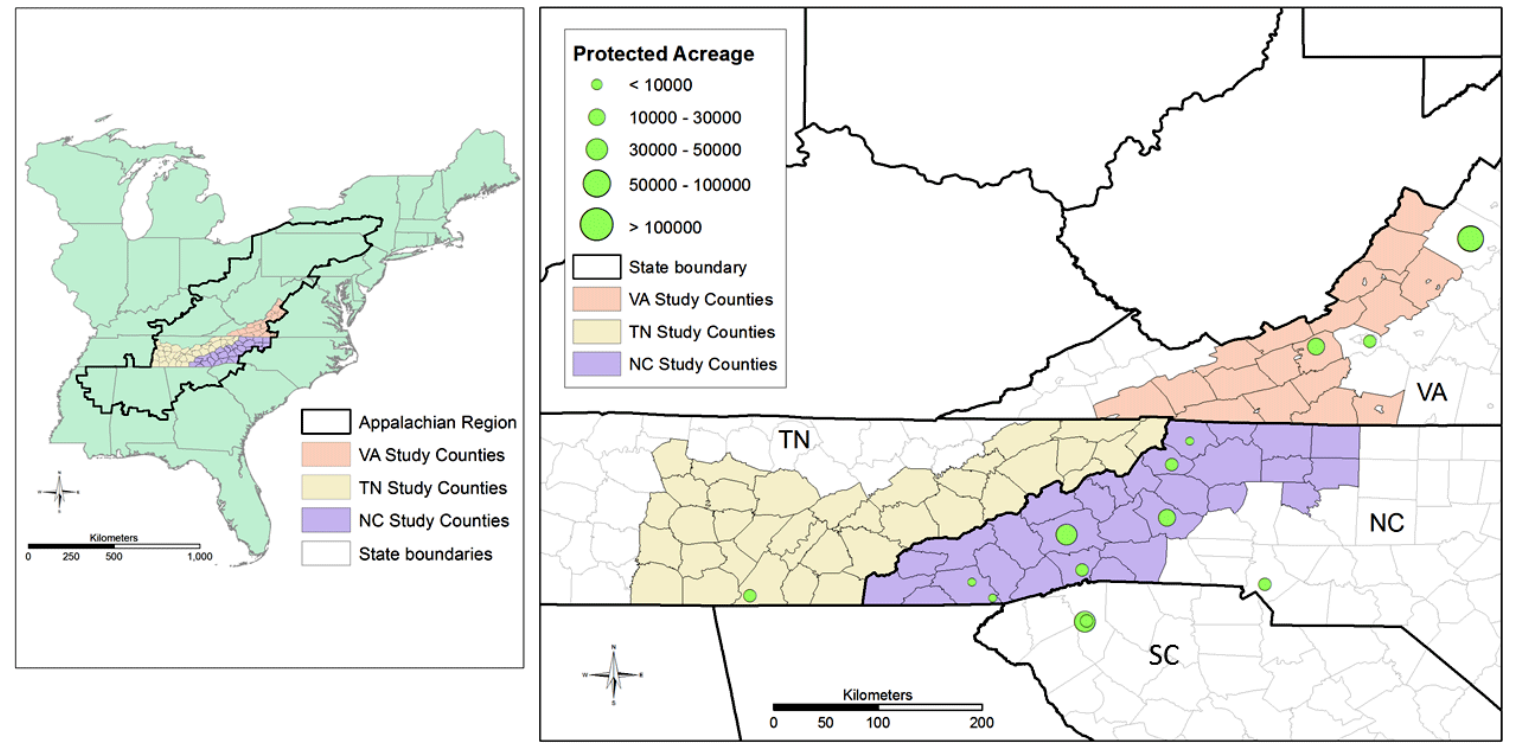

board and the land trust. Because social capital is typically used to maintain and expand organizational resources, we expect it to improve the capacity of land trusts to achieve their mission, conservation, and financial goals. In other words, the cognitive and structural dimensions of social capital will be positively related to the perceived performance of land trusts. Assuming differences among board members and their organizational affiliations account for differences in the perceived success of land trusts, we can employ both board member and land trust specific attributes in assessing perceptions of successful private land protection.

\section{METHODS}

\section{Study area}

South-central Appalachia encompasses 29 counties in western North Carolina, 18 in southwestern Virginia, and 38 in east Tennessee (Fig. 2). The area is defined by common topographic, demographic, and economic conditions, and is part of one of the oldest and most biodiverse temperate regions in the world. Land conservancies in the area work to protect the ecological integrity of the land in the face of competing human, e.g., mining, timbering, or second-home development, and nonhuman threats, e.g., climate change, invasive species. Historically, south-central Appalachia has been marginalized, predominantly rural, and economically underdeveloped, but today it mirrors trends characteristic of rural communities throughout the country, namely, socioeconomic decline due to a globalized economy, or growth due to tourism, recreation, and retirement in amenity-rich areas (Matarrita-Cascante et al. 2006, Hibbard and Lurie 2013). Often antiregulatory attitudes and poor or absent zoning present challenges to sustainable growth in these communities. Research suggests that in rural and economically disadvantaged areas, communities stand to benefit most from civic associations and social capital (Putnam 2000, Harrison et al. 2016).
In 2012, 24 land trusts (21 local and 3 state-wide) operated in the study area. From these, 16 groups (14 local, 2 state) participated in the study. A comparison of means test did not reveal significant differences in total number of acres conserved $(\mathrm{t}=1.44, \mathrm{p}<0.170)$, or total financial gifts and contributions received, between participating and nonparticipating organizations $(\mathrm{t}=-0.90, \mathrm{p}<$ 0.390 ). Because our focus was on local land trusts, the 2 statewide groups were excluded from the analysis, resulting in a final analysis sample of 14 organizations (Fig. 2).

Overall, the experience of these land trusts is comparable to others across the nation; however, their size (number of staff and board members) and conservation record, on average, slightly exceed the national average. The oldest land trust in the study area was founded in 1883. Four organizations were formed between 1950 and 1970, four in the 1980s, and the remaining ones in the post-1990 period. As reported in the 2010 Land Trust Alliance (LTA) Census, 1699 state and local land trusts had protected a total of 6.5 million ha (3829 ha on average). Per state/local land trust, protected lands equated to 2104 ha through conservation easements and 511 ha through fee simple ownership (LTA 2011). Additionally, the average US state/local land trust had 4 paid staff members, including full and part time, and 9 board members (LTA 2011). The 14 local land trusts in our analysis averaged 8.5 full and part time staff members and 17 board members in 2013 . According to LTA data, they had protected a total of 137,240 ha $($ mean $=9803$ ha, median $=6738$ ha $)$, with an average of 2625 ha protected by conservation easement $($ median $=1665 \mathrm{ha})$ and 520 ha through fee simple ownership (median $=294$ ha; LTA 2016). It is surmised that the study land trusts exceed national averages partly because of the following: past availability of state funds for land conservation (\$289 million during the peak 2007-2008 fiscal year compared with $\$ 40$ million for the 2015-2016 fiscal year for $\mathrm{NC}$ ); the percent of accredited land trusts that also have a 
strategic conservation plan (trusts that have a strategic plan conserve twice as many acres); and last, the fairly sizable geographic reach for these organizations ( 6 counties on average; LTA 2011, CTNC 2016).

\section{Data}

We collected data using interviews, a survey, and publicly available information on organizational web sites and tax forms. We conducted semistructured interviews with land trusts' executive directors to understand how they define and measure the success of their land trust (September 2012-April 2013). Additionally, each director was asked to identify the organizations their land trust collaborates with, the nature of these collaborations, and the extent to which collaborations contribute to the success of the land trust. Upon interviewees' consent, conversations were audiorecorded, then transcribed, and coded (Boyatzis 1998).

To understand how board members perceive and assess the success of their land trust we conducted a survey of land trust board members (February-June 2014), using a web and a mail questionnaire (Dillman 2009). This two-mode approach was adopted because of variations in the age and computer access of board members, as well as per directors' recommendations. The questionnaire contained 20 questions (78 items) measuring cognitive social capital, perceptions of land trust success, strategic goals achieved over the last 5 years, and demographics. From the total 239 board members representing the 14 local land trusts, we received 91 valid responses (64 online, 27 mailed questionnaires). The overall response rate was $38 \%$, and ranged by land trust from $5 \%$ to $83 \%($ mean $=41 \%$, std. dev. $=22 \%)$. Data limitations and respondent confidentiality did not allow us to test for the presence of nonresponse bias; we are therefore unable to explain the wide range in group-level response rates and/or rule out bias.

\section{Measures}

\section{Measuring success}

Success is a multidimensional concept, so we measured it through direct and indirect indicators consistent with the literature and our interviews. Traditional direct performance measures are money raised and land conserved (Rissman and Smail 2014). Common indirect performance measures include: mission relevance, reputation, community impact, organizational and membership growth, Land Trust Alliance accreditation, and meeting the organization's strategic goals (Erickson 2015). Therefore, we operationalize successful private land conservation as the degree to which board members perceive their land trust to successfully achieve its mission, as well as conservation and financial goals. Board member responses to the survey questions: "On a scale of 1-10, how successful do you feel your land trust is in achieving its: (a) mission, (b) conservation goals, (c) financial goals? $(1=$ not successful at all, $10=$ highly successful)," were aggregated to compute a mean measure of perceived land trust success. We also assessed how social capital affects perceived success controlling for actual success, i.e., the conservation and financial record of the organization. This approach allows us to understand how contextual factors influence subjective assessments of success. Direct indicators of the financial and conservation achievements of land trusts included change in acreage restricted by a conservation easement (2011-2013), and total public support in the form of gifts, grants, contributions, and membership fees (2009-2013).
Structural social capital

To uncover the level of structural and cognitive social capital among land trusts (Research Question 1) we used: (a) egocentric network approaches to compute measures of network structure (size, diversity); and (b) factor analysis to identify dimensions of cognitive social capital. These measures were used in the statistical analysis relating social capital to perceived land trust success.

We operationalized structural social capital as the size and diversity of organizational networks of both land trusts and their board members. We used a two-pronged approach for eliciting the organizational partners of land trusts. First, land trust executive directors were asked to name the organizations they collaborate with, using the following questions: Does the land trust collaborate with other organizations? If yes, which ones? What is the nature of this collaboration? Second, we conducted a systematic review of land trusts' websites to supplement this list. Next, each partner organization was assigned to one of five functional sectors: nonprofit, private, local government, state, or federal government. The assignment of organizational partners to sectors is based on a consideration of the range and diversity of resources available in different sectors. For each land trust we computed a diversity score based on sector representation using Shannon's diversity index (Shannon 1948). The formula for this measure is:

$$
\mathrm{H}=-\sum_{i=1}^{s} p_{i} \log p_{i}
$$

where $p$ is the proportion of organizations in category $i$, and $S$ is the number of categories ( $\mathrm{S}=5$ sectors). Higher scores indicate greater diversity or sector representation within a land trust's network (Andrevski et al. 2007, Siddiki et al. 2015). The index of functional network diversity reflects the breadth and depth of land trusts' organizational partnerships.

Board members' organizational networks were measured using responses to the following open-ended question: "Please, list other nonprofit organizations or groups you are active with, either in a membership or leadership position." We utilized the National Center for Charitable Statistics National Taxonomy of Exempt Entities (NTEE) codes to classify board members' organizational affiliations under one of 23 issue areas (Appendix 1). The mission of each nonprofit group was read independently by two researchers, who then assigned the nonprofit group an NTEE code. For groups without a mission statement, a keyword search was conducted using the NTEE online search engine, utilizing subgroup definitions. The extent to which code assignments were consistent across nonprofit groups was validated by comparing the mission statements of groups assigned to the same NTEE code, e.g., Education. A total of 270 nonprofit groups were reported by board members: 239 of these groups were coded by both researchers, 31 were coded by one researcher. The resulting intercoder agreement score was $92 \%(n=239)$. Where differences existed, the coders discussed and consulted with a third researcher before assigning an agreed-upon code. For each board member we then computed a diversity score based on the representation of NTEE codes within their organizational network. We followed Shannon's diversity index formula above to compute a measure of the issue diversity of board members' organizational networks, with $\mathrm{S}=23$ NTEE codes (Appendix 1). 
Cognitive social capital

Cognitive social capital is operationalized using survey responses to 32 statements measured on a 7-item agreement scale. Statements related to dimensions of cognitive social capital identified in the literature, namely trust, cooperation, reciprocity, common rules, and norms (Pretty 2003). Statements were adapted from the World Bank's social capital survey (Narayan 1999), and Fredette and Bradshaw's (2012) questionnaire on social capital and nonprofit governance. We performed principal axis factoring on the cognitive social capital items to identify key dimensions present in the data. An initial analysis of the 32 items detected the presence of 8 factors, but 4 items had low interitem correlations $(<0.2)$ and were excluded from subsequent analyses. The remaining 28 items contained 6 factors with Eigen values greater than 1 ; however, after the 4th factor changes in successive eigenvalues were small (Eigen value $<1.2$ ). Eight items were eliminated because they did not load on any factor or loaded on more than one factor. The resulting solution, based on principal axis factoring with promax rotation (power $=2$ ) produced four factors. The four factors for cognitive social capital were computed as the mean response on the variables loading above 0.4 .

\section{Other land trust and board member measures}

Board member survey responses were combined with land trust attributes identified in the literature and interviews as being important for the success of land trusts. We included covariates for the following land trust characteristics: organizational capacity measured as the sum of a land trust's full-time staff and board members; community support measured as number of volunteers; scale of operation, measured in number of counties in the land trust's geographic area of operation; LTA accreditation status, and organizational age. These were obtained from organizational websites, annual reports, and interviews with land trust executive directors. In addition, board members' demographics (standardized values for age, income, education) were combined into an additive socioeconomic status index and used as a measure of human capital. Survey responses to the openended question "What factors most contribute to your land trust's success?" were coded and thematically organized, using the constant comparative method (Boyatzis 1998). These themes were then used to guide the development of a multilevel regression model and selection of covariates.

\section{Multilevel model estimation}

We used a multilevel regression model to examine how structural and cognitive social capital relate to the perceived success of land trusts (Research Question 2). The approach allowed us to infer how board members' perceptions of successful land protection compare within and between land trusts, relative to types of social capital and contextual factors (Gelman 2006). The model explains board members' perceptions of successful land protection, given a set of individual (level 1) and organizational (level 2) characteristics. Notably, the results are limited to the respondent group and cannot be extended to other land trust board members in the study area.

A multilevel model provides more reliable estimates for hierarchically structured data, where board members are nested within land trusts, and such within-land trust dependence violates the homoscedasticity and error independence assumptions of the standard linear regression model (Rabe-Hesketh and Skondral 2005). Given the nested nature of our data, we expected a variance-components model to be most appropriate. To validate this assumption, we used Breusch and Pagan's Lagrange multiplier test on the unconditional variance components model (model 1 with no covariates) for the mean perceived level of success. The results confirmed our expectation that unobserved or unmeasured land trust characteristics drive variation among board members' perceptions of success. We thus estimate a series of linear random intercept models with cognitive social capital (model 2), with cognitive and structural social capital (model 3), and with additional individual- and organizational-level covariates (model 4).

The outcome of interest-mean level of perceived land trust success for board members nested within organizations-was modeled initially as a function of four cognitive social capital factors (cooperation, shared values, common norms, and communication effectiveness), controlling for board members' human capital and familiarity with the organization (years served on board; model 2). We next added structural social capital, measured by board members' and land trusts' organizational networks; the latter was weighted by the number of counties in the land trusts' geographic area to better account for variations in scale of operation and potential to create/maintain partnerships. We also included the sum of the two diversity indices to determine if functional network diversity (by sector and issue area) was related to perceptions of successful land protection (model 3). The full, model 4 included measures identified in the open-ended survey question as favorable to the success of a land trust, specifically: organizational resources, volunteer support, accreditation status, and organizational age (Appendix 1).

Because perceived success is shaped by positive experiences, we controlled for the conservation and financial achievements of land trusts, and their scale of operation (a binary control based on the average number of counties in the sample). The measures of acreage restricted by a conservation easement and public support were square-root transformed to correct for the left skew in the data, and an interaction effect for volunteers and level of public support was included. All individual-level covariates and the cross-level measure of network diversity were centered on their group means to allow more meaningful interpretations (RabeHesketh and Skrondal 2005). We assessed the model fit using the Bayesian Information Criterion (BIC), Akaike's Information Criterion (AIC), and residual diagnostics. The latter revealed the presence of one observation with an unusually large error; when removed, the model estimates improved. Analysis was performed in Stata 13 (StataCorp 2013).

\section{RESULTS}

\section{Cognitive and structural social capital}

The factor analysis resulted in the extraction of four main factors, consistent with our theoretical expectations. We gave each factor the following descriptive labels: Common norms, Shared values, Cooperation, and Communication effectiveness. Table 1 shows the loadings on the four factors, eigenvalues, percent of variance, and Cronbach's alpha. Post estimation checks revealed an 
Table 1. Factor loadings of cognitive social capital items on the four principle axes factors $(n=79)$. Loading values are from the pattern matrix and show the relationship between each observed variable and each factor. Principal Axis Factor Extraction with Promax Rotation (power $=4$ ), loadings $\geq 0.4$ used in the interpretation of each factor.

\begin{tabular}{|c|c|c|c|c|}
\hline Item & $\begin{array}{c}\text { Common } \\
\text { norms }\end{array}$ & $\begin{array}{c}\text { Shared } \\
\text { values }\end{array}$ & Cooperation & $\begin{array}{c}\text { Communication } \\
\text { effectiveness }\end{array}$ \\
\hline I am familiar with the norms governing the decisions and operations of this land trust & 0.834 & & & \\
\hline I know the policies and rules of this land trust & 0.884 & & & \\
\hline I participate in the development of the land trust's most important policies & 0.700 & & & \\
\hline $\begin{array}{l}\text { I feel the land trust has clearly defined processes and norms for identifying the common needs } \\
\text { and goals }\end{array}$ & 0.482 & & & \\
\hline $\begin{array}{l}\text { I feel most people on this board share my views on the future directions and goals for the land } \\
\text { trust }\end{array}$ & & 0.473 & & \\
\hline $\begin{array}{l}\text { Board members can be trusted to place the land trust mission above their personal values and } \\
\text { interests }\end{array}$ & & 0.445 & & \\
\hline Board members have no hidden agendas or issues & & 0.709 & & \\
\hline Board members agree on what is important for the success of this land trust & & 0.801 & & \\
\hline Board members share the same ambitions and vision for this land trust & & 0.785 & & \\
\hline Board members are committed to pursuing the goals and mission of the land trust & & 0.436 & & \\
\hline Board members share a common purpose regarding the land trust & & 0.530 & & \\
\hline Board members are in complete agreement on the vision for this land trust & & 0.607 & & \\
\hline Board members of this land trust can be trusted to contribute to the land trust's success & & & 0.488 & \\
\hline Board members view one another as partners in charting the direction of the land trust & & & 0.507 & \\
\hline $\begin{array}{l}\text { Most people on this board contribute time and/or money toward the common goals of the land } \\
\text { trust }\end{array}$ & & & 0.823 & \\
\hline Board members are always ready to cooperate and help each other & & & 0.513 & \\
\hline All board members are committed to making this land trust successful & & & 0.615 & \\
\hline I am comfortable sharing my personal ideas and feelings with other board members & & & & 0.848 \\
\hline Board members are considerate of views that differ from their own & & & & 0.605 \\
\hline Board members share and accept constructive criticism without making it personal & & & & 0.470 \\
\hline Eigenvalue & 11.711 & 2.551 & 1.785 & 1.433 \\
\hline Proportion explained (\%) & 41.826 & 9.110 & 6.377 & 5.117 \\
\hline Cronbach's alpha & 0.843 & 0.874 & 0.824 & 0.776 \\
\hline
\end{tabular}

adequate fit. Bartlett's test of sphericity was significant $(\mathrm{p}<0.00)$ and Kaiser's measure of sampling adequacy was above the minimum threshold of 0.6 (Kaiser-Meyer-Olkin MSA $=0.862$; Tabachnick and Fidell 2001). All factors are internally consistent and well-defined by the variables. The correlation matrix indicates moderate levels of association (Table 2).

Table 2. Correlations among the four cognitive social capital factors.

\begin{tabular}{lccc}
\hline \hline & Shared values & Cooperation & $\begin{array}{c}\text { Communication } \\
\text { effectiveness }\end{array}$ \\
\hline Common norms & $0.527^{* *}$ & $0.452^{* *}$ & $0.451^{* *}$ \\
Shared values & $(91)$ & $(90)$ & $(91)$ \\
& -- & $0.645^{* *}$ & $0.586^{* *}$ \\
Cooperation & -- & $(90)$ & $(91)$ \\
& & -- & $0.625^{* *}$ \\
** $\mathrm{p}<0.01$. Pearson's R correlation coefficient; sample size in \\
parenthesis.
\end{tabular}

Each cognitive social capital factor was computed as the mean response to the survey items listed in Table 1, and is interpretable in the original measurement scale; higher values represent greater agreement with the presence of a particular dimension of cognitive capital. We found considerably high levels of agreement with the presence of Cooperation, Shared values, Common norms, and Communication effectiveness among participating board members (Table 3 ). These factors vary more within land trusts, than between land trusts. The within land trust standard deviations for each factor were: Cooperation $(\mathrm{sd}=0.50)$, Shared values $(\mathrm{sd}=0.58)$, Common norms $(\mathrm{sd}=0.71)$, Communication ( $\mathrm{sd}=0.59)$; between land trusts standard deviations were: Cooperation $(\mathrm{sd}=0.29)$; Shared values $(\mathrm{sd}=0.44)$, Common norms ( $\mathrm{sd}=0.41)$, Communication $(\mathrm{sd}=0.33)$.

Summary descriptions of structural social capital and other variables used in the analysis are presented in Table 3. On average, board members were affiliated with about 3 other nonprofit groups, and there was substantial variation in both the size and diversity of their organizational affiliations. The average number of organizational partners for land trusts in this study was 25, with a minimum of 8 and a maximum of 46 partner groups. Relative to the number of counties in their geographic area, land trusts had 8 organizational partners, on average. Shannon's diversity index summarizes the functional network diversity of land trusts' and board members' organizational networks, by sector and issue area, respectively. There is more variability in functional diversity at the land trust than at the board member level (Table 3). 
Table 3. Definitions, data source, and descriptive statistics for variables used in the analysis.

\begin{tabular}{|c|c|c|c|c|c|c|c|c|}
\hline Variable & Definition & Source & $\mathrm{N}$ & Mean $^{\dagger}$ & SD & Median & Min & Max \\
\hline Land trust success & $\begin{array}{l}\text { Mean response to "How successful do you think your land } \\
\text { trust is in achieving its mission, conservation, and } \\
\text { financial goals?" ( } 1=\text { not successful at all; } 10=\text { highly } \\
\text { successful) }\end{array}$ & Board survey & 87 & 8.59 & 1.32 & 9.00 & 4.67 & 10 \\
\hline Cooperation & $\begin{array}{l}\text { Mean response to five items loading on the factor named } \\
\text { "Cooperation" }\end{array}$ & Board survey & 86 & 6.46 & 0.58 & 6.68 & 4.20 & 7.00 \\
\hline Shared values & $\begin{array}{l}\text { Mean response to eight items loading on the factor named } \\
\text { "Shared values" }\end{array}$ & Board survey & 87 & 6.06 & 0.69 & 6.00 & 4.00 & 7.13 \\
\hline $\begin{array}{l}\text { Communication } \\
\text { effectiveness }\end{array}$ & $\begin{array}{l}\text { Mean response to three items loading on the factor named } \\
\text { "Communication effectiveness" }\end{array}$ & Board survey & 87 & 6.31 & 0.65 & 6.33 & 4.67 & 7.00 \\
\hline Common norms & $\begin{array}{l}\text { Mean response to four items loading on the factor named } \\
\text { "Common norms" }\end{array}$ & Board survey & 87 & 6.18 & 0.78 & 6.25 & 3.00 & 7.00 \\
\hline Education & $\begin{array}{l}\text { Level of education }(1=\text { college, } 2=\text { graduate, } 3= \\
\text { professional) }\end{array}$ & Board survey & 87 & 1.81 & 0.78 & 2.00 & 1 & 3 \\
\hline Income & $\begin{array}{l}\text { Median of annual household income }(20,000 ; 60,000 \text {; } \\
100,000 ; 140,000 ; 180,000 ; 220,000 ; 260,000)\end{array}$ & Board survey & 84 & 152,346 & 73,673 & 140,000 & 20,000 & 260,000 \\
\hline Age & Board member's age in years & Board survey & 87 & 61.17 & 12.71 & 65 & 34 & 94 \\
\hline $\begin{array}{l}\text { Socioeconomic } \\
\text { status (SES) }\end{array}$ & $\begin{array}{l}\text { Board member's socioeconomic status as an average of the } \\
\text { standardized values for education, median income, and } \\
\text { age }\end{array}$ & Board survey & 81 & -0.00 & 0.57 & -0.03 & -1.05 & 1.16 \\
\hline Gender & Board member's gender $(0=$ female; $1=$ male $)$ & Board survey & 87 & 0.66 & 0.48 & 1 & 0 & 1 \\
\hline Years on board & Years respondent has been a board member $(<1$ year $=0)$ & Board survey & 88 & 5.19 & 4.84 & 4.00 & 0 & 25 \\
\hline $\begin{array}{l}\text { BM organizational } \\
\text { affiliations }\end{array}$ & $\begin{array}{l}\text { Number of nonprofit groups board members are active } \\
\text { with, either in a membership or leadership position }\end{array}$ & Board survey & 91 & 2.88 & 2.73 & 3.00 & 0 & 14 \\
\hline $\begin{array}{l}\text { LT organizational } \\
\text { partners }\end{array}$ & $\begin{array}{l}\text { Number of land trust's organizational partners in } \\
2013-2014\end{array}$ & $\begin{array}{l}\text { Interviews, } \\
\text { web sites }\end{array}$ & 91 & 24.63 & 11.01 & 26 & 8 & 46 \\
\hline $\begin{array}{l}\text { LT partners } \\
\text { weighted by } \\
\text { county }\end{array}$ & $\begin{array}{l}\text { Number of land trust's organizational partners divided by } \\
\text { the number of counties a land trust operates in }\end{array}$ & $\begin{array}{l}\text { Interviews, } \\
\text { web sites }\end{array}$ & 91 & 7.86 & 8.65 & 3.00 & 0.8 & 27 \\
\hline Diversity index & $\begin{array}{l}\text { Organizational network diversity as a sum of board } \\
\text { members' diversity index and land trusts' diversity index }\end{array}$ & $\begin{array}{l}\text { Board survey, } \\
\text { Interviews }\end{array}$ & 91 & 1.73 & 0.65 & 1.75 & 0.77 & 3.38 \\
\hline Accredited & $\begin{array}{l}\text { Whether land trust is accredited by the national Land } \\
\text { Trust Alliance }(1=\text { yes; } 0=\text { no })\end{array}$ & Board survey & 91 & 0.73 & 0.45 & 1.00 & 0 & 1 \\
\hline Capacity & $\begin{array}{l}\text { Organizational capacity measured as number of board } \\
\text { members and full-time staff members in } 2013\end{array}$ & IRS 990 form & 91 & 26.09 & 7.33 & 27 & 11 & 40 \\
\hline Volunteers & Number of volunteers in 2013 & IRS 990 form & 91 & 203.8 & 222.7 & 150 & 0 & 750 \\
\hline Organizational age & Number of years since land trust established (as of 2014) & Interviews & 91 & 28.76 & 18.23 & 24 & 4 & 105 \\
\hline Operational scale & Number of counties in a land trust's area of operation & Interviews & 91 & 5.81 & 3.00 & 6.00 & 1 & 11 \\
\hline County & $\begin{array}{l}\text { A binary measure for a land trust's area of operation, } \\
\text { based on the mean number of counties for the sample }(0= \\
\leq 6 \text { counties; } 1=>6 \text { counties })\end{array}$ & Interviews & 91 & 0.48 & 0.50 & 0 & 0 & 1 \\
\hline $\begin{array}{l}\text { Area under } \\
\text { conservation }\end{array}$ & $\begin{array}{l}\text { Change in area restricted by a conservation easement, in } \\
\text { hectares, for the } 2011-2013 \text { period }\end{array}$ & IRS 990 form $^{*}$ & 91 & 643.5 & 1312.7 & 144.9 & 0 & 4280.8 \\
\hline Public support & $\begin{array}{l}\text { Total gifts, grants, contributions, and membership fees } \\
\text { received for 2009-2013 period (in million US dollars) }\end{array}$ & IRS 990 form & 91 & 10.6 & 11.7 & 6.05 & 0.6 & 40.7 \\
\hline
\end{tabular}

Overall mean reported.

${ }^{\ddagger}$ Schedule D, Part II of IRS990 forms provided annual measures of the number of acres restricted by conservation easements. For those organizations where this schedule was missing, we used land trust annual reports and direct contact with the organizations to garner the data.

Land trusts averaged 26 board and staff members combined, with about 17 board members and 9 full-time staff members per land trust. Organizational capacity varied considerably among land trusts, reflecting differences in resources among groups in our study area. Some local groups encompassed as many as 11 counties in their geographic reach, while others were small land trusts operating in a single county (Table 3 ). The average scale of operation was 6 counties, and the mean organizational age was 29 years. Similarly, there was substantial variation in the area held under conservation easements (std. dev. $=1312.7$ ha) and money raised (std. dev. $=\$ 11,700,000)$. Board members brought a fairly high level of human capital to their land trusts, as summarized by their median annual income $(\$ 152,346)$, graduate degree achievements, and age. Most board members were predominantly male $(66 \%)$, had served on the board an average of 5 years, and were 61 years old, on average (Table 3 ).

Board members' responses about the factors that most contribute to their land trust's success were grouped into four main themes: Organizational capacity ( $58 \%$ of responses), Mission focus and values ( $24 \%)$, Contributions ( $10 \%)$, and Community connections $(8 \%$; Table 4). We used both the themes and subthemes (categories) to specify a set of covariates for the multilevel models of perceived success. 
Table 4. Factors contributing most to a land trust's success, by theme and subthemes $(n=91)$.

\begin{tabular}{lcc}
\hline \hline Themes & Frequency & Proportion \\
\hline Capacity & 58 & \\
$\quad$ Competent staff & 38 & 0.24 \\
Contributing board & 21 & 0.16 \\
$\quad$ Dedicated director & 15 & 0.09 \\
Leadership & 6 & 0.06 \\
$\quad$ Fundraising capacity & & 0.03 \\
Mission \& values & 21 & \\
$\quad$ Mission focus & 12 & 0.09 \\
$\quad$ Reputation & 9 & 0.05 \\
Conservation values & 7 & 0.04 \\
$\quad$ Natural resource endowments & 6 & 0.03 \\
$\quad$ Communication effectiveness & & \\
Contributions & 12 & 0.03 \\
$\quad$ Membership support & 11 & 0.05 \\
$\quad$ Financial contributions & 13 & \\
Community connections & 8 & 0.05 \\
$\quad$ Connections to the community & 237 & 0.03 \\
$\quad$ Organizational collaborations & & \\
Total & &
\end{tabular}

\section{Relating social capital to perceptions of land trust success} Model results are presented in Table 5. The unconditional random intercept model (model 1) provides a summary of the amount of variability in perceived success that exists between and within land trusts in the study. The intraclass correlation (rho) in the unconditional model represents the share of the group-level variance from the total variance $[0.475 /(0.475+1.255)=0.275]$. This measure was statistically significant and showed that roughly $28 \%$ of the variance in perceived success was attributable to land trust-specific factors, and $72 \%$ to board member-specific characteristics, i.e., within land trust variability $\left(L R \mathrm{X}^{2}=11.32\right.$, $\mathrm{df}=1, \mathrm{p}<0.00$; Table 5). We can infer that, for the respondent group, board member attributes explain much of the variation in perceptions of successful land protection.

Our results show that Cooperation and Shared values among board members contributed significantly and positively to their perceptions of land trust success. The inclusion of all four measures of cognitive social capital in the model is justified based on a Wald test $(w=69.95, \mathrm{df}=4, \mathrm{p}<0.00)$, though Cooperation and Shared values have a greater contribution to perceptions of success than the other two factors. Specifically, one point increase on the agreement scale of Cooperation corresponds, on average, to over half a point increase in the perceived level of success (model 2, Table 5).

Among the structural social capital measures, network diversity was positively and significantly associated with board members' perceptions of land trust success (model 3). Notably, the organizational affiliations of board members do not correspond in any significant or positive way to their perceptions of success. The size of land trusts' organizational networks, relative to their scale of operation, becomes important and statistically significant only when accounting for other organizational attributes (model 4). A potential explanation relates to the fact that for most land trusts organizational partnerships arise from specific conservation projects, and that many of these partnerships require time and capacity to cultivate. Model results further demonstrate that the contextual variables related to accreditation status, organizational capacity, age, volunteer, and public support, all contribute positively and significantly to board members' perceptions of success (model 4). As expected, the direct indicator of success, dollars raised, has a positive and significant association with board members' perceptions of land trust success; however, given the low magnitude of the coefficient, we are unable to determine whether this effect is substantively meaningful.

Variance components are reported at the bottom of Table 5. The individual-level variance summarizes the residual deviation across all board members for a land trust, and the group-level variance reports variability between land trusts in their mean level of perceived success. Conditional on all covariates (model 4), board members' perceptions of successful land protection vary more within land trusts, i.e., between board members of a land trust, than between land trusts (because individual variance is greater than the group-level variance).

We also examined the marginal effects of significant variables from the full model to clarify their relationship to board members' perceptions of success. Consistent with our expectations and the open-ended qualitative responses (Table 4), we found that greater organizational capacity (more than 26 board and staff members) is associated with higher levels of predicted board member perceptions of land trust success (Fig. 3). The lines in Fig. 3 reveal how the predicted level of perceived success changes across number of organizational partners and number of counties in a land trust's geographic area. For both low and high levels of organizational capacity (based on the sample mean of 26 staff and board members), the optimal size of a land trust's organizational network is greater than 10 partners per county. Notably, land trusts working in fewer than 3 counties are perceived by board members as less successful than land trusts operating across a larger geographic area (Fig. 3).

Fig. 3. Effect of land trust partnerships (panel A) and scale of operation (panel B) on perceptions of success, by organizational capacity. Bars represent $95 \%$ confidence intervals for the predicted values of perceived success.

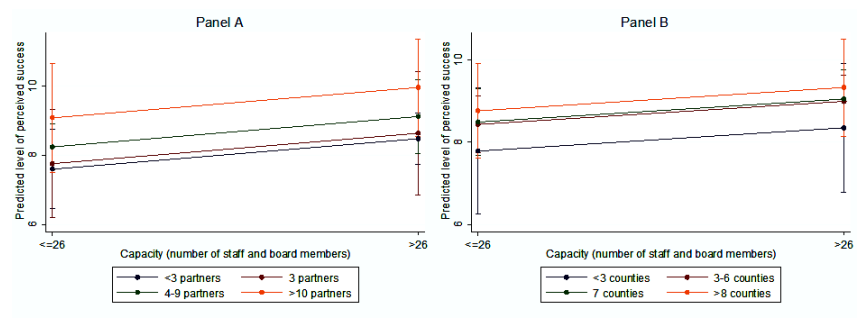

We also examined the marginal effect of cooperation and functional network diversity on the predicted level of perceived success, with the other covariates kept at their means (Fig. 4). Comparing the two panels of Fig. 4 we see that network diversity is associated with higher predicted values and greater variation in perceived success, than is cooperation. However, sufficiently high levels of cooperation among board members of a land trust provide fairly precise predictors of the degree to which land trusts 
Table 5. Multilevel model results for perceived land trust success.

\begin{tabular}{|c|c|c|c|c|}
\hline Variable & Model 1 & Model 2 & Model 3 & Model 4 \\
\hline \multicolumn{5}{|l|}{ Cognitive social capital } \\
\hline Cooperation & & $0.548^{* *}$ & $0.503^{* *}$ & $0.570^{* *}$ \\
\hline Shared values & & $0.558 * *$ & $0.605^{* * *}$ & $0.579 * * *$ \\
\hline Communication effectiveness & & 0.307 & 0.237 & 0.251 \\
\hline Common norms & & -0.090 & -0.004 & -0.036 \\
\hline \multicolumn{5}{|l|}{ Human capital } \\
\hline Socioeconomic status & & 0.202 & 0.218 & 0.170 \\
\hline Years served on board & & 0.016 & 0.001 & 0.001 \\
\hline \multicolumn{5}{|l|}{ Structural social capital } \\
\hline Boards' organizational affiliations & & & -0.113 & -0.089 \\
\hline Land trust partners per county & & & 0.026 & $0.061 * * *$ \\
\hline Diversity index & & & $0.685^{* *}$ & $0.579^{*}$ \\
\hline \multicolumn{5}{|l|}{ Land trust characteristics } \\
\hline Accredited & & & & $1.187 * * *$ \\
\hline Capacity & & & & $0.029^{*}$ \\
\hline Volunteers & & & & $0.006^{* * *}$ \\
\hline Organizational age & & & & $0.022 * * *$ \\
\hline County & & & & 0.071 \\
\hline Area under conservation & & & & 0.004 \\
\hline Public support & & & & $0.001 * * *$ \\
\hline Volunteers $\times$ Public Support & & & & $-0.000^{* * *}$ \\
\hline Constant & $8.577 * * *$ & $8.694 * * *$ & $8.540 * * *$ & $3.851 * * *$ \\
\hline Variance at group level & 0.475 & 0.916 & 0.860 & 0.000 \\
\hline Variance at individual level & 1.255 & 0.592 & 0.560 & 0.497 \\
\hline rho & $0.275^{* * *}$ & $0.607 * * *$ & $0.606^{* * *}$ & 0.000 \\
\hline Observations & 87 & 75 & 75 & 75 \\
\hline Groups & 14 & 14 & 14 & 14 \\
\hline $\mathrm{BIC}$ & 295.9 & 241.4 & 250.0 & 246.8 \\
\hline AIC & 288.5 & 220.5 & 222.2 & 200.5 \\
\hline
\end{tabular}

are perceived to achieve their mission, conservation, and financial goals. All predicted values in Fig. 3 and 4 are statistically significant (Tables A1.1 - A1.4).

Fig. 4. Effect of board member cooperation and network diversity on predicted perceptions of success. Both cooperation and network diversity are mean centered, with 0 representing the average level of cooperation and functional network diversity among land trusts in the sample. The shaded area is the $95 \%$ confidence interval of the marginal effects. Interval values are derived from model 4 (Table 5) with the mean values for all other covariates.

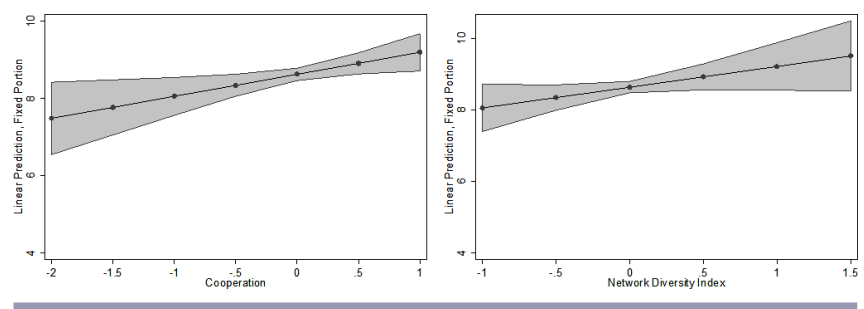

\section{DISCUSSION AND CONCLUSION}

Cooperation and shared values, along with the size and diversity of organizational networks were found to be important in perceptions of successful private land protection among board members in this study. These results illustrate the integrative and mutually reinforcing nature of both structural and cognitive social capital, a finding consistent with that in the literature (Pretty 2003, Knight et al. 2010). In the absence of organizational level characteristics (model 3), functional network diversity (bridging and linking social capital) had the greatest impact on perceptions of success for respondents in this study (coeff. $=0.685$, $p<0.05$; model 3 ). This suggests that the breadth and depth of organizational partnerships are important in explaining perceptions of success. These findings illustrate the value of relationship-building in the land conservation arena. It is through collaborations and genuine partnerships across sectors and issue areas that land trusts in this study are seen to effectively meet their strategic goals. Such relationships, beginning with the one between a land trust and a landowner, centered on the future use and stewardship of a social-ecological system, and evolving into a web of interactions with other organizations, illustrate the critical role social capital plays among participants in this study.

One could argue that bridging social capital is important because it allows land trusts to effectively meet and adapt to changing economic and policy realities, particularly by having access to functionally diverse resources (Rathwell and Peterson 2012). Bridging social capital could translate into funding and policyoriented collaborations with state and federal agencies, or privatesector partnerships with local businesses (brewing companies, restaurants, etc.). Funding-oriented collaborations are especially 
instrumental in the south-central Appalachian region, where state funding for conservation work has shrunk in the past few years. Groups that may have previously relied on support from state or federal funding agencies may now have shifted efforts to building relationships with local nonprofits and businesses within their own communities. The importance of volunteer support and financial contributions, found significant among land trusts in this study, adds further support for the value of relationshipbuilding within and across communities.

The importance of cognitive social capital in our analysis is consistent with studies showing that cooperation and collective action are easier when organizations (and individuals) have shared values, and constitute a fairly homogenous group (Pretty and Smith 2004, Ostrom 2005). Important dimensions of cognitive social capital for land trusts in this study included cooperation and shared values. Agreement about the presence of communication effectiveness and common norms was found to have no significant effect on participating board members' perceptions of success. Norms may vary across time and not all members may be familiar with the organization's bylaws and procedures, thus being less likely to agree with statements such as "I am familiar with the norms governing the decisions and operations of this land trust" (Table 1).

Board members' perceptions of successful land protection are also explained by land trust characteristics, namely organizational capacity, age, and accreditation status. Land trusts with low organizational capacity tend to be seen by board members in this study as less successful than high capacity organizations, a finding corroborated by the open-ended qualitative responses and the statistical model results. The greater the number of organizational partners per county and the larger the geographic reach of land trusts, the more successful these groups are perceived to be (Fig. 3). This finding is in line with explanations showing how resources embedded in social networks enable groups to combine existing organizational resources (capacity, human capital) with other assets (financial and natural capital) to coordinate action and achieve conservation goals (Coleman 1988, Narayan 1999). Greater levels of volunteer support and financial contributions are positively associated with perceptions of success among participants in this study.

Admittedly, a quantitative analysis has shortcomings both in terms of the measurement and validity of multidimensional concepts like social capital and success. Given the nature of our clustered data and multilevel model assumptions, our outcome of interest is constrained to board members' perceptions of land trust success. Establishing the veracity of reported levels of success can be problematic. Respondents may strategically answer questions about the success of their organization, as being unsuccessful may reflect poorly on their leadership or personal investment in the land trust. Future work should examine how directly observable indicators of land trust success relate to social capital, as a way to rule out potential social desirability effects in survey data. Time codetermination in the measurement of perceived success and cognitive social capital also needs to be taken into consideration in the interpretation of results.

Another important caveat is that findings are limited to the timeand context-specific achievements of participating land trusts in the rural communities of North Carolina, Virginia, and
Tennessee. There are considerable variations among rural communities with regard to what constitutes a rural county, and what type of resources and culture exist in these communities. Other potential factors affecting perceptions of land trust success that are not accounted for in this study include market forces and location. Land values, zoning, and local rules are structural variables influencing land use and community-based conservation. In addition, land trusts operating in proximity to urban centers or less mountainous areas may have more diverse organizational collaborations, because of the wider presence of federal agencies, conservation-minded partners, and access to funding, than land trusts in more rural, traditionally conservative areas. In many rural areas, attitudes and beliefs about the role of government in land use planning have challenged conservation efforts. As one land trust director put it, "relationship-building is absolutely key to so much of what we do. I am in a somewhat rural, traditionally conservative, Appalachian region where people are very suspicious of government. Local government doesn't want to be told too much what to do. I have some counties that don't have zoning..., so a lot of it is building relationships, building trust, explaining."

Given this standpoint and our results, there are several directions for land trusts considering strategies to enhance their board capital. First, to maximize access to needed resources land trusts should seek to recruit board members with diverse backgrounds and organizational affiliations, both within and beyond their communities. There is a strong association between the diversity of individuals' social relationships and a community's economic development, adaptive capacity, and innovation (Eagle et al. 2010, Jaskyte 2012, Harrison et al. 2016). Second, land trusts that aim to facilitate collective action should focus on creating conditions that enhance cooperation and shared values within the board, but also between the board and landowners. Fostering social relations through frequent contact with landowners or landowner-driven social capital models, such as peer-to-peer learning and collaborative landowner networks, has been shown to contribute positively to landowner satisfaction with easements and the longterm efficacy of conservation efforts (Rissman and Sayre 2012, Stroman and Kreuter 2014, 2015). Balancing the above two strategies may create a push-pull dynamic because too much diversity could negatively affect organizational cohesiveness; yet, bridging, linking, and bonding social capital can each play an important role in the degree to which land trusts are seen to successfully meet their goals.

Recent research on social networks calls for more research on intra-organizational level social capital (Berardo 2014). Broadly, we attempt to address this call by assessing how cognitive and structural social capital relates to the perceived success of nonprofit land trusts. We find that cooperation among board members and the diversity of organizational partnerships are associated with higher levels of perceived success. These results contribute to our knowledge of how features of social and governance systems can facilitate collective action locally to protect critical resources on private lands. To further the call for additional work on intra-organizational level social capital, replicating this study in other geographic areas could provide valuable insights given the variety of land characteristics and uses, demographic make-up of board members and residents, as well as age and size of land trusts. 
Additionally, a richer understanding of how board members view their role in the organization could provide an understanding of how a board member leverages their social connections. Future work could explore the effect of social capital on land trusts' relationships with landowners, and on the resilience of land trusts and their conservation landholdings (Stroman and Kreuter 2014, Sorice et al. 2014). Understanding the social capital of local, state, and regional government land management organizations could also be beneficial for the land protection community. These organizations have different structures and play an important role in private land protection. Last, exploring the importance of social relationships and norms from the standpoint of landowners could provide another view of how social capital contributes to the stewardship of private lands as important social-ecological systems.

Responses to this article can be read online at: http://www.ecologyandsociety.org/issues/responses. $\mathrm{php} / 8618$

\begin{abstract}
Acknowledgments:
We acknowledge support from Appalachian State University's Research Council Grant program. We thank the participating land trusts and the past director of the LTA Southeast Regional Program for their time and contributions. All authors contributed to the design of the research and data collection. TR performed the analyses, writing, and revisions of the manuscript. JF and CC provided valuable contributions to the manuscript revisions.
\end{abstract}

\section{LITERATURE CITED}

Andrevski, G., W. J. Ferrier, and D. J. Brass. 2007. Social capital and competitive behavior: a study of interfirm networks and rivalry among automakers. Academy of Management Proceedings 1:1-6. http://dx.doi.org/10.5465/AMBPP.2007.26530452

Ansell, C., and A. Gash. 2008. Collaborative governance in theory and practice. Journal of Public Administration Research and Theory 18:543-571. http://dx.doi.org/10.1093/jopart/mum032

Berardo, R. 2014. Bridging and bonding capital in two-mode collaboration networks. Journal of Policy Studies 42(2):197-225. http://dx.doi.org/10.1111/psj.12056

Bodin, Ö., and C. Prell. 2011. Social networks and natural resource management: uncovering the social fabric of environmental governance. Cambridge University Press, New York, New York, USA. http://dx.doi.org/10.1017/cbo9780511894985

Borgatti, S. P., and P. C. Foster. 2003. The network paradigm in organizational research: a review and typology. Journal of Management 29(6):991-1013. http://dx.doi.org/10.1016/S0149-2063 (03)00087-4

Borgatti, S. P., C. Jones, and M. G. Everett. 1998. Network measures of social capital. Connections 21(2):27-36.

Boyatzis, R. E. 1998. Transforming qualitative information: thematic analysis and code development. Sage, Thousand Oaks, California, USA.
Bradshaw, P., V. Murray, and J. Wolpin. 1996. Women on boards of nonprofits: What difference do they make? Nonprofit Management \& Leadership 6:241-254. http://dx.doi.org/10.1002/ $\underline{n m l .4130060304}$

Brenner, J. C., S. Lavallato, M. Cherry, and E. Hileman. 2013. Land use determines interest in conservation easements among private landowners. Land Use Policy 35:24-32. http://dx.doi. org/10.1016/j.landusepol.2013.03.006

Brown, W. A. 2007. Board development practices and competent board members: implications for performance. Nonprofit Management \& Leadership 17(3):301-317. http://dx.doi. org/10.1002/nml.151

Burt, R. S. 2000. The network structure of social capital. Pages 345-423 in R. I. Sutton and B. M. Staw, editors. Research in organizational behavior, Volume 22. JAI Press, Greenwich, Connecticut, USA. http://dx.doi.org/10.1016/s0191-3085(00) 22009-1

Coleman, J. S. 1988. Social capital in the creation of human capital. American Journal of Sociology 94(Suppl.):S95-S120. http://dx.doi.org/10.1086/228943

Conservation Trust for North Carolina (CTNC). 2016. State funding and tax incentives: NC's successful conservation trust funds. CTNC, Raleigh, North Carolina, USA. [online] URL: http://www.ctnc.org/assist/advocacy/state-funding-tax-incentives

Cox, M., G. Arnold, and S. Villamayor Tomás. 2010. A review of design principles for community-based natural resource management. Ecology and Society 15(4):38. [online] URL: http:// www.ecologyandsociety.org/vol15/iss4/art38/

Dietz, T., E. Ostrom, and P. C. Stern. 2003. The struggle to govern the commons. Science 302:1907-1912. http://dx.doi.org/10.1126/ science. 1091015

Dillman, D. A. 2009. Internet, mail, and mixed-mode: the tailored design method. John Wiley \& Sons, Hoboken, New Jersey, USA.

Eagle, N., M. Macy, and R. Claxton. 2010. Network diversity and economic development. Science 328:1029-1031. http://dx.doi. org/10.1126/science.1186605

Erickson, D. 2015. Measuring success. Saving Land Magazine Winter 2015:43(1).

Farmer, J. R., D. Knapp, V. J. Meretsky, C. Chancellor, and B. C. Fischer. 2011. Motivations influencing the adoption of conservation easements. Conservation Biology 25:827-834. http:// dx.doi.org/10.1111/j.1523-1739.2011.01686.X

Fischer, A. P., K. Vance-Borland, K. M. Burnett, S. Hummel, J. H. Creighton, S. L. Johnson, and L. Jasny. 2014. Does the social capital in networks of "fish and fire" scientists and managers suggest learning? Society \& Natural Resources 27(7): 671-688. http://dx.doi.org/10.1080/08941920.2014.901463

Fredette, C., and P. Bradshaw. 2012. Social capital and nonprofit governance effectiveness. Nonprofit Management and Leadership 22(4):391-401. http://dx.doi.org/10.1002/nml.21037

Gelman, A. 2006. Multilevel (hierarchical) modeling: what it can and cannot do. Technometrics 48(3):432-435. http://dx.doi. org/10.1198/004017005000000661 
Grootaert, C., and T. van Bastelaer. 2002. Understanding and measuring social capital: A multi-disciplinary tool for practitioners. The World Bank, Environmentally and Socially Sustainable Development Network, Washington, D.C., USA. http://dx.doi. org/10.1596/0-8213-5068-4

Gustanski, J. A., and R. H. Squires. 2000. Protecting the land: conservation easements past, present, and future. Island Press, Washington, D.C., USA.

Harrison, J. L., C. A. Montgomery, and J. C. Bliss. 2016. Beyond the monolith: the role of bonding, bridging, and linking social capital in the cycle of adaptive capacity. Society \& Natural Resources 29(5):525-539. http://dx.doi.org/10.1080/08941920.20$\underline{15.1103389}$

Hibbard, M., and S. Lurie. 2013. The new natural resource economy: environment and economy in transitional rural communities. Society \& Natural Resources 26(7):827-844. http:// dx.doi.org/10.1080/08941920.2012.720358

Hillman, A., and T. Dalziel. 2003. Boards of directors and firm performance: integrating agency and resource dependence perspectives. Academy of Management Review 23:383-396.

Imperial, M. T. 2005. Using collaboration as a governance strategy: lessons from six watershed management programs. Administration and Society 37(3):281-320. http://dx.doi. org/10.1177/0095399705276111

Jaskyte, K. 2012. Boards of directors and innovation in nonprofit organizations. Nonprofit Management and Leadership 22 (4):439-459. http://dx.doi.org/10.1002/nml.21039

King, M. A., and S. K. Fairfax. 2006. Public accountability and conservation easements: learning from the Uniform Conservation Easement Act debates. Natural Resources Journal 46:65-129.

Knight, A. T., R. M. Cowling, M. Difford, and B. M. Campbell. 2010. Mapping human and social dimensions of conservation opportunity for the scheduling of conservation action on private land. Conservation Biology 24(5):1348-1358. http://dx.doi. org/10.1111/j.1523-1739.2010.01494.X

Land Trust Alliance (LTA). 2011. The 2010 national land trust census report: a look at voluntary land conservation in America. Land Trust Alliance, Washington, D.C., USA. [online] URL: http://s3.amazonaws.com/landtrustalliance.org/page/ files/2010LandTrustCensus.pdf

Land Trust Alliance(LTA). 2016. Find a land trust alliance member land trust near you. Land Trust Alliance, Washington, D.C., USA. [online] URL: http://findalandtrust.org/

Lichtsteiner, H., and V. Lutz. 2012. Use of self-assessment by nonprofit organization boards: the Swiss case. Nonprofit Management \& Leadership 22(4):483-506. http://dx.doi. org/10.1002/nml.21041

Lin, N. 2001. Social capital: a theory of social structure and action. Cambridge University Press, Cambridge, UK. http://dx.doi. org/10.1017/cbo9780511815447

Mandarano, L. A. 2009. Social network analysis of social capital in collaborative planning. Society \& Natural Resources 22:245-260. http://dx.doi.org/10.1080/08941920801922182
Matarrita-Cascante, D., A. E. Luloff, R. S. Krannich, and D. R. Field. 2006. Community participation in rapidly growing communities in southern Utah. Community Development 37:71-87. http://dx.doi.org/10.1080/15575330609490196

Narayan, D. 1999. Bonds and bridges: social capital and poverty. Policy Research Working Paper 2167. The World Bank, Washington, D.C., USA. [online] URL: http://info.worldbank. org/etools/docs/library/9747/narayan.pdf

Ostrom, E. 1990. Governing the commons. The evolution of institutions for collective action. Cambridge University Press, Cambridge, UK. http://dx.doi.org/10.1017/CBO9780511807763

Ostrom, E. 2005. Understanding institutional diversity. Princeton University Press, Princeton, New Jersey, USA.

Pahl-Wostl, C., M. Craps, A. Dewulf, E. Mostert, D. Tabara, and T. Taillieu. 2007. Social learning and water resources management. Ecology and Society 12(2):5. [online] URL: http:// www.ecologyandsociety.org/vol12/iss $2 / \operatorname{art} 5 /$

Paletto, A., F. Ferretti, and I. De Meo. 2012. The role of social networks in forest landscape planning. Forest Policy and Economics 15:132-139. http://dx.doi.org/10.1016/j.forpol.2011.11.007

Pretty, J. 2003. Social capital and the collective management of resources. Science 302:1912-1914. http://dx.doi.org/10.1126/ science. 1090847

Pretty, J., and D. Smith. 2004. Social capital in biodiversity conservation and management. Conservation Biology 18:631-638. http://dx.doi.org/10.1111/j.1523-1739.2004.00126.x

Pretty, J., and H. Ward. 2001. Social capital and the environment. World Development 29:209-227. http://dx.doi.org/10.1016/ $\underline{\mathrm{S} 0305-750 \mathrm{X}(00) 00098-\mathrm{X}}$

Putnam, R. D. 2000. Bowling alone. The collapse and revival of American community. Simon \& Schuster, New York, New York, USA. http://dx.doi.org/10.1145/358916.361990

Rabe-Hesketh, S., and A. Skrondal. 2005. Multilevel and longitudinal modeling using stata. Volume I: Continuous responses. Third Edition. Stata, College Station, Texas, USA.

Rathwell, K. J., and G. D. Peterson. 2012. Connecting social networks with ecosystem services for watershed governance: a social-ecological network perspective highlights the critical role of bridging organizations. Ecology and Society 17(2):24. http:// dx.doi.org/10.5751/ES-04810-170224

Rissman, A. R., and N. F. Sayre. 2012. Conservation outcomes and social relations: a comparative study of private ranchland conservation easements. Society \& Natural Resources. 25 (6):523-538. http://dx.doi.org/10.1080/08941920.2011.580419

Rissman, A. R., and R. Smail. 2014. Accounting for results: how conservation organizations report performance information. Environmental Management 55(4):916-929. http://dx.doi.org/10.1007/ $\underline{\mathrm{s} 00267-014-0435-3}$

Schneider, M., J. Scholz, M. Lubell, D. Mindruta, and M. Edwardsen. 2003. Building consensual institutions: networks and the National Estuary Program. American Journal of Political Science 47(1):143-158. http://dx.doi.org/10.1111/1540-5907.00010 
Shannon, C. E. 1948. A mathematical theory of communications. Bell System Technical Journal 27:397-423. http://dx.doi. org/10.1002/j.1538-7305.1948.tb01338.x

Siddiki, S. N., J. L. Carboni, C. Koski, and A.-A. Sadiq. 2015. How policy rules shape the structure and performance of collaborative governance arrangements. Public Administration Review 75(4):536-547. http://dx.doi.org/10.1111/puar.12352

Sorice, M. G., U. P. Kreuter, B. P. Wilcox, and W. E. Fox III. 2014. Changing landowners, changing ecosystem? Land-ownership motivations as drivers of land management practices. Journal of Environmental Management 133:144-152 http://dx.doi.org/10.1016/ j.jenvman.2013.11.029

StataCorp. 2013. Stata Statistical Software: Release 13. Stata, College Station, Texas, USA.

Stroman, D., and U. P. Kreuter. 2015. Factors influencing land management practices on conservation easement protected landscapes. Society \& Natural Resources 28:891-907. http://dx. doi.org/10.1080/08941920.2015.1024365

Stroman, D. A., and U. P. Kreuter. 2014. Perpetual conservation easements and landowners: evaluating easement knowledge, satisfaction and partner organization relationships. Journal of Environmental Management 146:284-291. http://dx.doi.org/10.1016/ j.jenvman.2014.08.007

Tabachnick, B. G., and L. S. Fidell. 2001. Using multivariate statistics. Fourth edition. Ally \& Bacon, Needham Heights, Massachusetts, USA.

Vidovich, L., and J. Currie. 2012. Governance networks: interlocking directorships of corporate and nonprofit boards. Nonprofit Management and Leadership 22(4):507-523. http://dx. doi.org/10.1002/nml.21042

Woolcock, M. 2001. The place of social capital in understanding social and economic outcomes. Canadian Journal of Policy Research 2:11-17.

Yonavjak, L., and T. Gartner. 2011. Gaining ground: increasing conservation easements in the U.S. South. World Resources Institute Brief 7. [online] URL: http://pdf.wri.org/gaining ground. pdf 


\section{Appendix 1}

National Center for Charitable Statistics NTEE codes: Board members' organizational affiliations were coded using the following 23 NTEE categories: (1) Arts, (2) Education, (3) Environment, (4) Animal-related, (5) Health care, (6) Voluntary health associations, (7) Medical research, (8) Crime \& Legal-related, (9) Employment, (10) Food, Agriculture, and Nutrition, (11) Housing, (12) Public safety, (13) Recreation \& Sports, (14)Youth development, (15)Voluntary health associations, (16) Homeless centers, (17) Civil rights, (18) Community improvement, (19) Philanthropy, (20) Public \& Societal benefit, (21) Religion, (22) Mutual \& membership benefit, and (23) Unknown. (Source: http://nccsweb.urban.org)

\section{Multi-level model estimation}

Results for model 4, Table 5 are derived from a linear random intercept model with both individual- and organizational-level covariates. The functional form of the model is as follows:

$$
\begin{aligned}
& y_{i j}=\alpha_{\mathrm{j}}+\beta_{1} \cdot \text { Coop }_{\mathrm{ij}}+\beta_{2} . \text { Values }_{\mathrm{ij}}+\beta_{3} . \text { Norms }_{\mathrm{ij}}+\beta_{4} \cdot \text { Comm }_{\mathrm{ij}}+\beta_{5} . \text { SES }_{\mathrm{ij}}+\beta_{6} . \text { Time }_{\mathrm{ij}}
\end{aligned}
$$

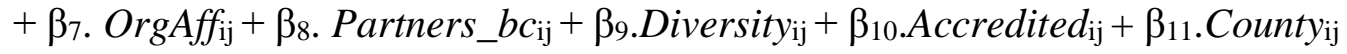

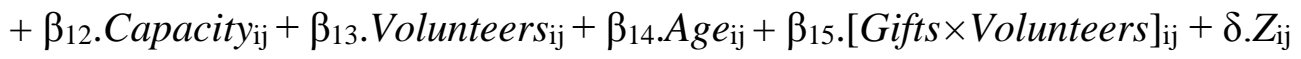

$$
\begin{aligned}
& +\zeta_{\mathrm{j}}+\varepsilon_{\mathrm{ij}},
\end{aligned}
$$

where $y_{i j}$ is the reported mean level of land trust success for board member $i$ in land trust $j$. This outcome is modeled as a function of four cognitive social capital factors (Cooperation, Shared values, Common norms, and Communication effectiveness), board member's human capital (SES), and number of years serving on the board (Time). The organizational affiliations of board members (OrgAff), and organizational partners of land trusts, weighted by the number of counties a land trust operates in (Partners_bc), represent the level of structural social capital. We also include a test of the hypothesis that functional network diversity (Diversity) is positively related to perceptions of successful land protection. Diversity represents a cross-level interaction (sum) of the land trusts' diversity index and board members' diversity index. Prior to inputting it in the model, the summative Diversity index was centered on the group (land trust) mean. Other factors identified in the open-ended survey questions as favorable to the success of a land trust are: organizational Capacity, number of Volunteers, organizational longevity (Age), and a binary control measure for the number of counties a land trust operates in (County) $(1>6$ counties; $0 \leq 6$ counties). The interaction effect for volunteers and public support (Gifts) is denoted by $\beta_{15}$. Finally, $Z_{\mathrm{ij}}$ represents the directly observable measures of land trusts' conservation and financial achievements. The change in total area restricted by a conservation easement and total public support were square-root transformed to correct for the left skew in the data. All level-1 covariates, including the summative Diversity index were centered on their sample means to allow more meaningful interpretations (Rabe-Hesketh and Skrondal 2005). Finally, the group-level variance, $\zeta_{\mathrm{j}}$, is the variance component that allows the intercept $\left(\alpha_{\mathrm{j}}\right)$ to vary between land trusts, and $\varepsilon_{\mathrm{ij}}$ is the individual-level, board member-specific error component. The variance component $\zeta$ j represents the combined effects of omitted land trust attributes or unobserved heterogeneity at the group level. The model thus can be viewed as a linear mixed-effects model with both fixed and random effects. We estimated the model with restricted maximum likelihood (REML) and maximum likelihood (ML) estimation. Because no substantively meaningful differences were found, we report the results based on ML. In addition, model results were compared against results 
from an ordinal multi-level regression model, with perceived success divided into quartiles and used as an ordinal response variable. No significant differences were detected between the continuous and ordinal response models.

\section{Statistical significance results for marginal effects shown in Fig. 3 and Fig. 4}

Table A1.1 Statistical significance for the predicted values (margins) of perceived success by number of organizational partners per county and land trust organizational capacity

\begin{tabular}{lllllll}
\hline Covariates & Margin & Std. Error & $\mathbf{z}$ & $\mathbf{P}>|\mathbf{z}|$ & $\mathbf{9 5 \%} \mathbf{C I}$ \\
\hline $\begin{array}{l}\text { Fewer than 3 partners } \\
\quad \text { Low capacity }\end{array}$ & 7.61 & 0.56 & 13.65 & 0.00 & 6.52 & 8.71 \\
$\quad$ High capacity & 8.46 & 0.37 & 23.15 & 0.00 & 7.75 & 9.18 \\
$\begin{array}{l}\text { 3 partners } \\
\quad \text { Low capacity }\end{array}$ & 7.73 & 0.77 & 10.08 & 0.00 & 6.22 & 9.23 \\
$\quad$ High capacity & 8.58 & 0.88 & 9.79 & 0.00 & 6.86 & 10.29 \\
$\begin{array}{l}\text { 4-9 partners } \\
\quad \text { Low capacity }\end{array}$ & 8.25 & 0.32 & 25.52 & 0.00 & 7.61 & 8.88 \\
$\quad$ High capacity & 9.10 & 0.52 & 17.50 & 0.00 & 8.08 & 10.12 \\
More than 10 partners & & & & & & \\
$\quad$ Low capacity & 9.15 & 0.77 & 11.82 & 0.00 & 7.63 & 10.66 \\
$\quad$ High capacity & 10.00 & 0.69 & 14.52 & 0.00 & 8.65 & 11.35 \\
\hline
\end{tabular}

Predicted values based on results from model 4, Table 5, with all model variables held at their mean values. Low organizational capacity < = sample mean of 26 staff and board members; High organizational capacity $>26$ staff and board members.

Table A1.2 Statistical significance for predicted values (margins) of perceived success by land trusts' scale of operation (number of counties) and organizational capacity

\begin{tabular}{lllllll}
\hline Covariates & Margin & Std. Error & $\mathbf{z}$ & $\mathbf{P}>|\mathbf{z}|$ & $\mathbf{9 5 \%} \mathbf{C I}$ \\
\hline $\begin{array}{c}\text { Fewer than 3 counties } \\
\text { Low org capacity }\end{array}$ & 7.77 & 0.75 & 10.42 & 0.00 & 6.31 & 9.24 \\
$\quad$ High org capacity & 8.32 & 0.77 & 10.86 & 0.00 & 6.82 & 9.82 \\
$\begin{array}{c}\text { 3-6 counties } \\
\quad \text { Low org capacity }\end{array}$ & 8.43 & 0.34 & 24.77 & 0.00 & 7.76 & 9.10 \\
$\quad$ High org capacity & 8.97 & 0.31 & 28.66 & 0.00 & 8.36 & 9.58 \\
$\mathbf{7}$ counties & & & & & & \\
$\quad$ Low org capacity & 8.49 & 0.40 & 21.46 & 0.00 & 7.72 & 9.27 \\
$\quad$ High org capacity & 9.03 & 0.35 & 25.95 & 0.00 & 8.35 & 9.72 \\
More than 8 counties & & & & & & \\
$\quad$ Low org capacity & 8.84 & 0.57 & 15.62 & 0.00 & 7.73 & 9.95 \\
$\quad$ High org capacity & 9.38 & 0.58 & 16.17 & 0.00 & 8.24 & 10.52 \\
\hline
\end{tabular}

Predicted values based on results from model 4, Table 5, with all model variables held at their mean values. Low organizational capacity <= sample mean of 26 staff and board members; High organizational capacity $>26$ staff and board members. 
Table A1.3 Statistical significance for the predicted values (margins) of perceived success by levels of cooperation

\begin{tabular}{llllllll}
\hline Cooperation value & $\begin{array}{l}\text { Centered } \\
\text { value }\end{array}$ & Margin & $\begin{array}{l}\text { Std. } \\
\text { Error }\end{array}$ & $\mathbf{z}$ & $\mathbf{P}>|\mathbf{z}|$ & 95\% & CI \\
\hline 1=Strongly disagree & -2.0 & 7.48 & 0.48 & 15.64 & 0.00 & 6.54 & 8.42 \\
2=Disagree & -1.5 & 7.77 & 0.36 & 21.36 & 0.00 & 7.05 & 8.48 \\
3=Somewhat disagree & -1.0 & 8.05 & 0.25 & 32.11 & 0.00 & 7.56 & 8.54 \\
4=Neutral & -0.5 & 8.34 & 0.14 & 57.49 & 0.00 & 8.05 & 8.62 \\
5=Somewhat agree & 0.0 & 8.62 & 0.08 & 105.75 & 0.00 & 8.46 & 8.78 \\
6=Agree & 0.5 & 8.90 & 0.14 & 63.40 & 0.00 & 8.63 & 9.18 \\
\hline
\end{tabular}

Predicted values based on results from model 4, Table 5, with all model variables held at their mean values. Centered values represent the standardized values for the cognitive social capital factor "Cooperation".

Table A1.4 Statistical significance for the predicted values (margins) of perceived success by network diversity

\begin{tabular}{llllllll}
\hline $\begin{array}{l}\text { Network } \\
\text { diversity value }\end{array}$ & $\begin{array}{l}\text { Centered } \\
\text { value }\end{array}$ & Margin & $\begin{array}{l}\text { Std. } \\
\text { Error }\end{array}$ & $\mathbf{z}$ & $\mathbf{P}>|\mathbf{z}|$ & 95\% CI \\
\hline $\mathbf{1 . 0 8}$ & -1.0 & 8.05 & 0.34 & 24.02 & 0.00 & 7.39 & 8.71 \\
$\mathbf{1 . 4 1}$ & -0.5 & 8.34 & 0.18 & 46.12 & 0.00 & 7.99 & 8.70 \\
$\mathbf{1 . 7 3}$ & 0.0 & 8.63 & 0.08 & 105.90 & 0.00 & 8.47 & 8.79 \\
$\mathbf{2 . 0 6}$ & 0.5 & 8.92 & 0.18 & 48.26 & 0.00 & 8.56 & 9.28 \\
$\mathbf{2 . 3 8}$ & 1.0 & 9.21 & 0.34 & 27.12 & 0.00 & 8.54 & 9.88 \\
$\mathbf{2 . 7 1}$ & 1.5 & 9.50 & 0.50 & 19.00 & 0.00 & 8.52 & 10.48 \\
\hline
\end{tabular}

Predicted values based on results from model 4, Table 5, with all model variables held at their mean values. Centered values represent the standardized values for Diversity Index, with a sample mean of 1.73 and standard deviation of 0.65 (See Table 3). 